С. В. КаАенко, В. В. Циганок

Інститут проблем реєстрації інформації НАН України

вул. М. Шпака 2, 03113, Київ, Україна

\title{
Визначення відносної компетентності експертів піА час агрегації парних порівнянь
}

Показано, щзо для визначення відносної компетентності експертів, які вводять оцінки у вигляді матриць парних порівнянь, недостатньо враховувати лише самооцінку, взаємну оцінку та так звану об'єктивну компоненту даного показника. Запропоновано метод визначення відносної компетентності членів експертної групи під час агрегації парних порівнянь альтернатив або варіантів рішення, який дозволяє врахувати всі складові компетентності: апріорну оцінку за трьома вказаними компонентами, повноту, узгодженість і докладність оцінок, що надані експертом. Так, під час агрегаиії, судженням експерта, який $\epsilon$ більш послідовним у своїх оцінках, і надає більш детальну інформачію (обираючи шкали з більшою кількістю поділок), доцільно присвоювати більшу вагомість. Отримано експериментальні результати, які емпірично підтверджують необхідність урахування різних аспектів компетентності експертів під час проведення експертиз. Отриманий результат дозволяс удосконалити наявні методи агрегації експертних парних порівнянь (зокрема, комбінаторний метод) і підвищити достовірність результатів групових експертиз, у яких використовуються групові парні порівняння.

Ключові слова: відносна компетентність експерта, експертна група, підтримка прийняття рішень, матриия парних порівнянь, шкала експертного оцінювання, узгодженість експертних оцінок.

\section{Вступ: актуацьність і стан проблеми}

Визначення відносної компетентності експертів $є$ актуальною проблемою під час прийняття будь-якого рішення невеликою групою експертів (у [1] показано, що якщо експертна група налічує кілька десятків членів, то різницею в їхній компетентності можна знехтувати). Судження найбільш компетентного експерта мусять мати найбільшу відносну вагу і найбільш сильний вплив на підсумкове рішення всієї експертної групи (незалежно від того, відкрито, чи анонімно експерти висловлюють свої думки).

(C) С. В. Каденко, В. В. Циганок 
До проблеми визначення відносної компетентності експертів зверталися численні автори, як у світі, так і на пострадянському просторі.

3-поміж вербальних засобів оцінки компетентності, у світі широкої популярності набув підхід, що запропонований Дрейфусом [2, 3], згідно з яким спеціалістів у певній галузі можна поділити на п'ять кваліфікаційних рівнів (новачок, компетентний спеціаліст, професіонал, експерт і майстер; у більш пізній публікації новачок, передовий початківець, компетентний спеціаліст, професіонал та експерт) за низкою ознак. Ознаки включають здатність до пригадування (неситуативного, ситуативного чи контекстно-незалежного), розпізнавання (декомпозованого чи цілісного), прийняття рішень (аналітичного чи інтуїтивного) і обізнаність чи готовність до дій (моніторинг ситуації, або постійне ментальне перебування у предметній області)).

У різного роду опитуваннях [4] часто використовується підхід, за яким закріпилася назва «метод снігового кому». Так, потенційних членів експертної групи просять назвати ще кількох спеціалістів у відповідній галузі. Відповідно, відносна компетентність експерта визначається частотою його входження у списки спеціалістів, названих іншими експертами.

Численні праці визнаних зарубіжних та українських авторів у сфері експертних технологій, зокрема [5-12], вказують на такі основні компоненти показника компетентності експерта як: 1) самооцінка; 2) взаємна оцінка компетентності членів експертної групи; 3) об'єктивна складова.

Ці складові можуть оцінюватися на основі бальних шкал, анкетування [12], тестів із запитаннями різних типів і рівнів складності [10], парних порівнянь [7-9, 13].

Як зазначено, зокрема, у [14], однією із ознак слабко структурованої предметної області є неможливість чисельного (кількісного) опису об'єктів. Одним із найбільш дієвих інструментів подолання даної проблеми $є$ попарне порівняння об'єктів, які неможливо кількісно описати. В рамках даної статті увагу буде зосереджено якраз на проблемі визначення відносної компетентності експертів під час агрегації парних порівнянь, тому має сенс зробити короткий огляд розробок зарубіжних та українських колег саме у цьому напрямку.

На заході своєрідною монополією у сфері методів підтримки прийняття рішень на основі парних порівнянь (у тому числі, групових) користуються автор методів аналізу ієрархій і мереж Т. Сааті [7] та його послідовники. Даною науковою школою протягом останніх кількох десятиліть запропоновано низку підходів до визначення показників відносної компетентності експертів, які слід використовувати під час агрегації результатів групових парних порівнянь.

Власне, у [7] Т. Сааті пропонує сформувати ієрархію таких факторів як «навички», «досвід», «попередні досягнення», «здатність до переконання», «докладені зусилля» тощо і обраховувати компетентність експертів як агреговану оцінку за цими критеріями (знов-таки, на основі агрегації власних векторів матриць парних порівнянь (МПП), як це робиться у самому методі аналізу ієрархій). Якщо особа, що приймає рішення (ОПР), не в змозі оцінити експертів за переліченими критеріями, то пропонується доручити задачу самооцінки та взаємної оцінки самим експертам. При цьому експертів пропонується вважати рівно-компетентними. Раманатан і Ганеш [8] пропонують під час взаємної оцінки не наділяти експертів рів- 
ною компетентністю, а скласти матрицю з ваг альтернатив, що отримані на основі індивідуальних МПП $W=\left(\vec{w}_{1}, \ldots, \vec{w}_{m}\right)(m-$ кількість експертів) і шукати показники відносної компетентності експертів як координати власного вектора цієї матриці на основі рівняння $\lambda \vec{x}=W \vec{x}$. Ці ж два підходи (Сааті та Раманатана) пропонують використовувати Форман і Пеніваті [9]. Ще один підхід до визначення відносної компетентності (вагомості) експертів пропонується Янгом та ін. у [13]. Автори, фактично, використовують інструментарій двох методів: аналізу ієрархій i TOPSIS (описаного, зокрема, у [15]) і пропонують визначати вагомість експертних суджень на основі їхньої віддаленості від найгірших і найкращих оцінок у вибірці («ідеальних альтернатив»).

Радянські та українські автори також зверталися до проблеми визначення компетентності експертів під час агрегації парних порівнянь (зокрема, у [5, 6, 10, $11,16,17])$. Тоценко, спираючись на дослідження Міркіна та Литвака, пропонує визначати узагальнений показник відносної компетентності експертів як добуток самооцінки та зваженої суми взаємної оцінки і об'єктивної компоненти (див. формулу (1) нижче). Гнатієнко та Снитюк у своїй монографії [10] наводять два основних підходи: визначення компетентності експерта: 1) на основі результату опитування (відповіді на низку питань різних типів) та 2) на основі результатів парних порівнянь (значень переваг) альтернатив, заданих експертом у ході експертизи. МПП апроксимується так званим гіперпаралелепіпедом вагових коефіцієнтів (ГВК). Чим більшим є його «об’єм» $V=\left(\prod_{i \in I}\left(\rho_{i}^{\max }-\rho_{i}^{\min }\right)\right)^{1 / n}$, «периметр граней» або «площа поверхні» $S=\frac{1}{n} \sum_{i \in I}\left(\rho_{i}^{\max }-\rho_{i}^{\min }\right)$ (які залежать від різниць між верхніми та нижніми межами значень ваг об’єкта з номером $\left.i\left(\rho_{i}^{\max }, \rho_{i}^{\min }\right)\right)$, тим менш узгодженою є матриця, і тим менш компетентним слід вважати відповідного експерта.

Наведений стислий огляд методів визначення відносної компетентності експертів в ході агрегації індивідуальних оцінок свідчить про те, що кожен 3 них враховує лише якийсь один аспект компетентності членів експертної групи: об'єктивну складову $([7,10,12])$ взаємну оцінку чи самооцінку $([8])$, взаємну узгодженість ([13]), чи внутрішню узгодженість ([10]) експертних оцінок.

Отже, виникає потреба у розробці показника відносної компетентності, який дозволив би врахувати самооцінку, взаємну оцінку та об'єктивну оцінку компетентності, а також - внутрішню та взаємну узгодженість експертних суджень. До того ж, доцільно вимагати, щоб показник компетентності враховував детальність шкал, які використовує експерт для введення парних порівнянь (чим більш детальною $є$ шкала, тим більшою вагою слід наділяти судження відповідного експерта). Тобто, показник компетентності має відображати як апріорну оцінку компетентності експерта, так і оцінку його компетентності з огляду на якість інформації, введеної ним під час експертизи. У даній статті пропонується метод визначення компетентності експертів, який дозволяє врахувати всі перелічені аспекти.

\section{Контекст дослідження та постановка задачі}

У контексті поточних досліджень авторів даної статті актуальність визначення відносної компетентності експертів зумовлена участю експертних груп у процесі 
стратегічного планування в слабко структурованих предметних областях, описаного, зокрема, у [18]. Процес стратегічного планування включає наступні етапи:

1) формулювання головної цілі;

2) підбір експертів для проведення експертизи;

3) побудова (в процесі діалогу з експертами) ієрархії критеріїв (системи показників), що описують предметну область;

4) оцінка експертами відносних впливів критеріїв (проектів) ієрархії;

5) визначення оптимальної стратегії розвитку галузі як раціонального варіанта розподілу ресурсів між проектами.

У цьому процесі відносна компетентність експертів відіграє найбільш суттєву роль на етапі агрегації оцінок. Утім, і на етапі побудови ієрархії, коли експерти пропонують свої формулювання назв критеріїв, цілей і проектів, інженер по знаннях також має враховувати їхню відносну компетентність. Отже, на етапі підбору експертів слід визначити значення їхньої відносної компетентності.

Задача визначення відносної компетентності експертів під час групових парних порівнянь формулюється наступним чином.

Нехай на проміжному етапі побудови певної стратегії за методикою, що описана у [18], група $3 m$ експертів оцінює $n$ об'єктів шляхом парних порівнянь у шкалах різної докладності. Результатом роботи експертів $є m$ матриць парних порівнянь: $\left\{A^{(k)} ; k=1 . . . m\right\}=\left\{a_{i j}^{k}: k=1 \ldots m ; i, j=1 . . . n\right\}$.

Tреба знайти коефіцієнти відносної компетентності кожного з членів експертної групи, які найбільш повно відбивають його знання у кожному питанні та можуть бути використані для агрегації (згортки) оцінок, наданих усіма експертами: $c_{l}: l=[1 \ldots m]: \sum_{l=1}^{m} c_{l}=1$.

\section{ІАея розв'язання заАачі}

Донедавна при визначення відносної компетентності експертів автори статті віддавали перевагу підходам, викладеним В.Г.Тоценком [11] та його послідовниками (наприклад, у [19]). Як зазначалося вище, основними компонентами коефіцієнта відносної компетентності $l$-го члена експертної групи $c_{l} \in$ самооцінка, взаємна оцінка, та об'єктивна складова (позначимо їх, відповідно, $c_{l, \text { self }}, c_{l, \text { obj }}, c_{l, \text { mutual }}$ ):

$$
c_{l}=c_{l, \text { self }}\left(x_{1} c_{l, o b j}+x_{2} c_{l, \text { mutual }}\right) .
$$

У (1) $x_{1}, x_{2}$ - відповідно, відносні ваги об'єктивної та взаємної оцінки компетентності членів експертної групи.

Утім, у світлі останніх досліджень авторів, зокрема, удосконалення комбінаторного методу агрегації парних порівнянь [20] та розробки технології експертного оцінювання з використанням різних шкал [21], постала необхідність перегляду наявних підходів до визначення відносної компетентності експертів і їхнього удосконалення з метою врахування всіх перелічених вище аспектів.

Якщо під час експертизи група експертів оцінює низку альтернатив шляхом їхніх парних порівнянь, то концептуально, компетентність експертів доцільно розглядати на кількох рівнях (рухаючись від загального до одиничного), а саме: 
1) рівень поточних досягнень експерта у заданій предметній області взагалі;

2) рівень конкретної експертизи;

3) рівень сеансу парних порівнянь певної множини об'єктів (результатом якого є матриця парних порівнянь);

4) рівень окремого парного порівняння у вибраній шкалі.

Розглянемо окремо кожен із перелічених рівнів.

1. Компетентність експерта на рівні всієї предметної області відображають показники взаємної оцінки, самооцінки та об'єктивної складової, що фігурують у формулі (1).

2. Компетентність у контексті конкретної експертизи можна визначити за базовими ключовими словами (БКС), які описують головну ціль цієї експертизи. Принципи визначення компетентності експерта щодо БКС (знов-таки, на основі трьох вищезгаданих компонент) описані Тоценком у [11]. Тоценко пропонує описувати задачу за допомогою ієрархії базових ключових слів. Ненормований коефіцієнт компетентності $j$-го експерта за $h$-м ключовим словом, що знаходиться на $i$-му рівні ієрархії $k_{j i h}^{*}$ пропонується обчислювати за формулою:

$$
k_{j i h}^{*}=v_{j i h}\left(x_{1} o_{j i h}+x_{2} w_{j i h}\right) .
$$

У формулі (2) $x_{1}, x_{2}$ — відповідно, відносні ваги об'єктивної і взаємної оцінки компетентності членів експертної групи, а $v_{j i h}, o_{j i h}, w_{j i h}-$ відповідно, самооцінка, об'єктивна, та взаємна оцінки рівня компетентності експерта за заданим ключовим словом.

Для визначення взаємної оцінки, самооцінки, об'єктивної оцінки та відносних ваг компонент $x_{1}, x_{2}$ пропонується використовувати методи, перелік і стислий огляд яких наведено у вступній частині даної статті.

Перш ніж переходити до інших концептуальних рівнів, слід нагадати, що у загальному випадку експертні оцінки власної компетентності та компетентності членів експертної групи будуть тією чи іншою мірою суб'єктивними (і залежатимуть, знов-таки, від обізнаності самих експертів). Крайній випадок суб'єктивності самооцінки експерта ілюструється так званим ефектом Даннінга-Крюгера [22]. Так, спеціаліст з низьким рівнем компетентності схильний до завищення самооцінки, а спеціаліст з трохи вищим рівнем компетентності - до заниження самооцінки, і лише дійсно компетентний спеціаліст здатен адекватно оцінити власну компетентність.

3. Компетентність члена експертної групи, який вводить матрицю парних nорівнянь, може бути визначена за принципом, наведеним у [23]. Принцип полягає в тому, щоб вважати найбільш компетентним експерта, МПП якого є найбільш узгодженою i, водночас, близькою до відповідних МПП, уведених іншими членами групи.

У рамках комбінаторного методу агрегації групових парних порівнянь, який описано в [20], з метою найбільш повного використання експертної інформації, МПП кожного експерта декомпозуються на базисні зв'язні множини парних порівнянь, за якими будуються ідеально узгоджені МПП (ІУМПП) [20, 23]. Кожній такій ІУМПП присвоюється рейтинг, який відображає компетентність експерта на 
рівні певної базисної (інформаційно-вагомої) множини парних порівнянь об'єктів [23].

Рейтинг певної ІУМПП залежить від її «близькості» до реальних МПП, уведених експертами. Доцільно вважати, що чим більш віддаленою від реальних матриць є ІУМПП, тим нижчим має бути їі рейтинг (адже така віддаленість вказує на внутрішню та взаємну неузгодженість МПП). Отже, у [23] як рейтинг ІУМПП пропонується обрати величину, обернену до логарифму суми модулів відстаней між відповідними елементами матриць (див. формули (3) та $(3, a))$. Операція логарифмування використовується для уникнення завеликих різниць між рейтингами матриць і забезпечує перебування рейтингів у межах одного порядку.

$$
\begin{gathered}
R_{k q l}=\frac{c_{k} c_{l}}{\ln \left(\sum_{u, v}\left|a_{u v}^{k q}-a_{u v}^{l}\right|+e\right)}, \\
R_{k q l}=\frac{c_{k} c_{l}}{\log _{2}\left(\sum_{u, v}\left|a_{u v}^{k q}-a_{u v}^{l}\right|+2\right)} .
\end{gathered}
$$

У формулах (3) та $(3, a) R_{k q l}$ - рейтинг ІУМПП, побудованої за інформаційно-вагомою множиною парних порівнянь 3 номером $q$, взятою $з$ реальної МПП експерта 3 номером $k$, яка порівнюється із реальною МПП експерта з номером $l$; $a_{u v}^{k q}$ та $a_{u v}^{l}$ - відповідні елементи ІУМПП $k$-го експерта з номером $q$ та реальної МПП $l$-го експерта; $c_{k}, c_{l}$ - коефіцієнти відносної компетентності експертів 3 номерами $k, l$, що відповідають 1-му та 2-му вищеописаним концептуальним рівням.

У [23] розглядається випадок адитивних парних порівнянь. Тобто умова транзитивності (внутрішньої узгодженості) МПП записується як $\forall i, j=1 \ldots n: a_{i j}=w_{i}-w_{j}=\left(w_{i}-w_{k}\right)+\left(w_{k}-w_{j}\right)=a_{i k}+a_{k j}$, де $n$ - загальна кількість альтернатив, що попарно порівнюються, $w_{i}, w_{j}$ - відносні ваги альтернатив 3 відповідними номерами. Для випадку мультиплікативних парних порівнянь (коли умова транзитивності (внутрішньої узгодженості) МПП записується як $\left.\forall i, j=1 \ldots n: a_{i j}=\frac{w_{i}}{w_{j}}=\frac{w_{i}}{w_{k}} \times \frac{w_{k}}{w_{j}}=a_{i k} \times a_{k j}\right)$ можна запропонувати альтернативні формули для обрахунку рейтингів ІУМПП, де знак суми замінюється добутком:

$$
\begin{gathered}
R_{k q l}=\frac{c_{k} c_{l}}{\ln \left(\prod_{u, v} \max \left(\frac{a_{u v}^{k q}}{a_{u v}^{l}} ; \frac{a_{u v}^{l}}{a_{u v}^{k q}}\right)+e-1\right)}, \\
R_{k q l}=\frac{c_{k} c_{l}}{\log _{2}\left(\prod_{u, v} \max \left(\frac{a_{u v}^{k q}}{a_{u v}^{l}} ; \frac{a_{u v}^{l}}{a_{u v}^{k q}}\right)+1\right)} .
\end{gathered}
$$


Втім, слід зазначити, що операції логарифмування та подальшого нормування рейтингів матриць суттєво згладжують різницю між рейтингами, тому принциповим $\epsilon$ не конкретний варіант формули, а сам факт урахування внутрішньої та взаємної узгодженості МПП експертів під час визначення їхньої відносної компетентності.

Знаменники дробів у формулах (3), (3,a), (4), (4,a) відображають різницю між відповідними матрицями парних порівнянь. Чим більшою $є$ ця різниця, тим менш узгодженими слід вважати оцінки відповідного експерта. ІУМПП, які побудовані на основі суджень заданого експерта, порівнюються з реальними МПП, заданими як ним самим, так і всіма іншими членами експертної групи $(k, l=1 \ldots m)$. Це дозволяє врахувати як внутрішню, так і зовнішню узгодженість оцінок.

Грубу чисельну оцінку порядку знаменників дробів у формулах (3) та (4) можна отримати наступним чином.

Припустімо, що усі значення парних порівнянь у матрицях вводяться у цілочисельній шкалі з 9-ти поділок, яка, зазвичай, використовується у методі аналізу ієрархій. Дана кількість поділок є максимальною з огляду на відомі психофізіологічні обмеження людини (експерта), яка здатна одночасно зіставляти та аналізувати не більше (7士2) об’єктів одного порядку. Нехай порівнюються дві МПП.

Розглянемо гіпотетичний екстремальний випадок. Нехай усі значення над головною діагоналлю першої матриці (у якій стоять одиниці $\left(a_{i i}=1\right)$ ) дорівнюють максимальній поділці шкали, тобто $9\left\{a_{i j}^{1}=9, i, j=1 \ldots . n, i<j\right\}$, а другої - мінімальній поділці, тобто $1 / 9\left\{a_{i j}^{2}=1 / 9, i, j=1 \ldots . n, i<j\right\}$.

Якщо чисельник дробу у формулі (3) прийняти за одиницю (вважати експертів рівно компетентними (ненормовані значення $\left.c_{1}=c_{2}=1\right)$ ), то отримаємо:

$$
R_{12}=\frac{1}{\ln \left(\sum_{u, v=1}^{n}\left|a_{u v}^{1}-a_{u v}^{2}\right|+e\right)}=\frac{1}{\ln \left(e+n(n-1)\left(9-\frac{1}{9}\right)\right)} \approx \frac{1}{\ln (e+8,89 n(n-1))} .
$$

Тобто, діапазон рейтингів матриць для адитивного вигляду показника (формула (3)) - наступний:

$$
1 \geq R_{k q l} \geq \frac{1}{\ln (e+8,89 n(n-1))} .
$$

Наприклад, для кількості альтернатив $n=4,1 \geq R_{k q l} \geq \frac{1}{4,695} \approx 0,213$, для $n=9$ (максимальна кількість альтернатив, які одночасно можна давати експерту для порівняння) $1 \geq R_{k q l} \geq \frac{1}{6,466} \approx 0,155$.

Аналогічно, для мультиплікативного вигляду формули рейтингу (4): 


$$
\begin{gathered}
R_{12}=\frac{1}{\ln \left(\coprod_{u, v=1}^{n} \max \left(\frac{a_{u v}^{2}}{a_{u v}^{1}} ; \frac{a_{u v}^{1}}{a_{u v}^{2}}\right)+e-1\right)}=\frac{1}{\ln \left(\left(\frac{9}{1 / 9}\right)^{n(n-1)}+e-1\right)}=\frac{1}{\ln \left(e-1+81^{n(n-1)}\right)} \approx \\
\approx \frac{1}{n(n-1) \ln 81} \approx \frac{1}{4,39 n(n-1)} .
\end{gathered}
$$

Тобто, діапазон рейтингів матриць для мультиплікативного вигляду показника (формула (4)) - наступний:

$$
1 \geq R_{k q l} \geq \frac{1}{4,39 n(n-1)} .
$$

Так, наприклад, для $n=4,1 \geq R_{k q l} \geq 0,019$, для $n=9: 1 \geq R_{k q l} \geq 0,003$.

Вигляд формул (3), (3,a), (4), (4,a), а також наведені оцінки діапазонів рейтингів дозволяють зробити наступний висновок. Якщо ОПР зацікавлена у тому, щоб результати експертизи максимально повно відображали різницю у компетентності експертів, то слід обирати мультиплікативний вигляд формули для обчислення рейтингу МПП та меншу основу логарифму.

4. На рівні окремого парного порівняння компетентність експерта пропонується визначати за степенем детальності шкали, у якій введене це парне порівняння. Експерта, який готовий ввести парне порівняння у більш детальній шкалі, доцільно вважати більш компетентним, коли йдеться про відповідну пару об'єктів. Для врахування даної складової компетентності експерта у [21] запропоновано присвоювати кожному парному порівнянню, заданому у певній шкалі, вагу, що пропорційна кількості інформації, яка міститься у даній шкалі. Кількість інформації, що міститься у шкалі з $N$ поділок обчислюється за формулою Хартлі [24] як двійковий логарифм від $N: S_{N}=I=\log _{2} N$.

Виходячи з цього, рейтинг (вагу) базисної множини парних порівнянь $n$ об'єктів (про яку йдеться вище), пропонується обчислювати як середнє геометричне рейтингів (ваг) складових цієї множини. Так, середня ненормована вага $q$-ї базисної множини парних порівнянь, взятої з індивідуальної матриці парних порівнянь об'єктів, побудованих $k$-м експертом, дорівнюватиме:

$$
s^{k q}=\left(\prod_{u=1}^{n-1} \log _{2} N_{u}^{(k q)}\right)^{\frac{1}{n-1}} .
$$

За теоремою Кейлі про дерева [25] загальна кількість базисних множин, які будуються на основі цілком заповненої МПП $n$ об'єктів, дорівнює $n^{n-2}$. Якщо матриця $є$ неповною (експерт не задав значення порівнянь для деяких пар альтернатив), то кількість таких базисних множин дорівнюватиме $T \in\left(0, . ., n^{n-2}\right)$. У формулі (5) діапазон $\{q=1 \ldots T\}$.

Відповідно, якщо йдеться про всю індивідуальну матрицю парних порівнянь, заданих експертом з номером $k$, то іiї рейтинг (вагомість) з огляду на докладність шкал, використаних експертом для кожного парного порівняння, пропонується обчислювати за формулою: 


$$
s^{k}=\left(\prod_{\substack{u, v=1 \\ v>u}}^{n} \log _{2} N_{u v}^{(k)}\right)^{\frac{2}{n(n-1)}} .
$$

За побудовою, матриця є обернено-симетричною, тому ми розглядаємо лише трикутний фрагмент над головною діагоналлю $(v>u)$.

Усі перелічені складові відносної компетентності експертів слід враховувати під час агрегації експертних парних порівнянь і їхніх результатів.

\section{Практичне застосування підходу: удосконалення комбінаторного методу агрегації парних порівнянь}

3 огляду на викладені міркування, у комбінаторний метод агрегації парних порівнянь, описаний у $[20,23]$, пропонується внести певні удосконалення, що дозволять зробити результати його застосування більш адекватними реальному рівню компетентності учасників експертизи.

Комбінаторний метод застосовується у процесі стратегічного планування $[18,21]$ на етапі експертної оцінки відносних впливів факторів, що впливають на головну ціль стратегічного плану. Вибір комбінаторного методу 3-поміж інших методів агрегації групових парних порівнянь зумовлений можливістю максимально повного використання експертної інформації та іншими перевагами, продемонстрованими у [26].

Нагадаймо, що у комбінаторному методі на основі індивідуальних МПП, побудованих експертами, комбінуються по черзі базисні множини парних порівнянь (так звані, покривні дерева). За кожною такою множиною можна обчислити нормовані ваги об'єктів: $\left\{w_{j}^{q}, j=1 \ldots n, q=1 \ldots T\right\}$. Відповідно, без урахування відносної компетентності експертів, формула для обчислення агрегованих значень ваг $n$ об'єктів ( $\left.w_{j}^{\text {aggregate }}, j=1 . . . n\right)$ на основі МПП, заданих $m$ експертами, методом середнього геометричного, має наступний вигляд:

$$
w_{j}^{\text {aggregate }}=\left(\prod_{q=1}^{T} w_{j}^{q}\right)^{\frac{1}{T}}, j=1 \ldots n, T \in\left[1 \ldots m n^{n-2}\right] .
$$

Для врахування внутрішньої та взаємної узгодженості МПП під час агрегації значень ваг пропонується присвоювати кожній ІУМПП (та відповідному вектору ваг), побудованій на основі індивідуальної МПП конкретного експерта, певний рейтинг (як зазначено в попередньому пункті). Для введення рейтингу, який має відображати внутрішню узгодженість парних порівнянь з МПП заданого експерта та взаємну узгодженість МПП різних експертів, пропонується створити $m$ копій кожної ІУМПП. У результаті буде отримано $T^{*}=m T$ ІУМПП $\left(m \leq T^{*} \leq m^{2} n^{n-2}\right)$. Також, окрім узгодженості оцінок, цей рейтинг має враховувати рейтинг шкал, якими користується експерт для парних порівнянь (4-й концептуальній рівень) i величину відносної компетентності експерта на рівні предметної області та експертизи загалом (1-й та 2-й рівні). 3 урахуванням наведених міркувань, пропонується обчислювати рейтинг кожної окремої ІУМПП (і відповідного вектора ваг) 3-поміж усіх $T^{*}=m T$ ІУМПП за наступною формулою: 


$$
\begin{gathered}
R_{k q l}=\frac{c_{k} c_{l} s^{k q} s^{l}}{\ln \left(\sum_{u, v}\left|a_{u v}^{k q}-a_{u v}^{l}\right|+e\right)}, \\
R_{k q l}=\frac{c_{k} c_{l} s^{k q} s^{l}}{\ln \left(\prod_{u, v} \max \left(\frac{a_{u v}^{k q}}{a_{u v}^{l}} ; \frac{a_{u v}^{l}}{a_{u v}^{k q}}\right)+e-1\right)} .
\end{gathered}
$$

У формулах (8) та $(8, a) k, l$ - номери експертів $(k, l=1 \ldots m)$, чиї МПП порівнюються; $c_{k}, c_{l}$ — коефіцієнти відносної компетентності, що відповідають рівням предметної області та, власне, експертизи; ще раз наголосимо, що $k$ та $l$ можуть бути рівними чи різними, тобто ІУМПП, яка побудована на основі індивідуальної МПП, заданої експертом з номером $k$, може порівнюватись із самою цією МПП (внутрішня узгодженість) і з МПП інших експертів (взаємна узгодженість); $q$ - номер «копії» ІУМПП $\left(q=1 . . . m T_{k}\right) ; s^{k q}-$ відносна усереднена вага шкал, у яких вводилися відповідні парні порівняння з відповідної базисної множини (формула (5)); $s^{l}$ - середня вага шкал, у яких вводилася відповідна індивідуальна МПП експерта номер $l$ (обчислюється за формулою (6)). Якщо у формулі (7) врахувати рейтинги ІУМПП, то отримаємо наступний вираз для агрегованих значень ваг об'єктів:

$$
w_{j}^{\text {aggregate }}=\prod_{k, l=1}^{m}\left(\prod_{q^{k}=1}^{T_{k}}\left(w_{j}^{\left(k q_{k} l\right)}\right)^{\left.\frac{R_{k, p, v} R_{k p v}}{\sum_{u, k}}\right), j=1 . . . n .}\right.
$$

\section{Експериментацьне досліАження методу; чисельний приклаА}

Удосконалений комбінаторний метод агрегації парних порівнянь тестувався на багатьох чисельних прикладах за допомогою макету, що моделює групову експертизу, реалізованого у пакеті MS Excel. Тестування показало, що результати групових парних порівнянь, які отримано з урахуванням і без урахування компетентності експертів, суттєво відрізняються між собою. Цей факт ще раз підтверджує необхідність врахування всіх аспектів відносної компетентності експертів у ході агрегації парних порівнянь, адже в цьому випадку результати експертизи більш адекватно відображають знання експертів.

Звичайно ж, якщо всі експерти використовують однакову шкалу, а їхні судження $\epsilon$ ідеально узгодженими, то відповідні концептуальні рівні компетентності не відіграють помітної ролі (як можна побачити з попередніх двох розділах даної статті). Проте, в умовах реальних експертиз ситуація, зазвичай, $є$ протилежною.

У даному розділі пропонується розглянути чисельний приклад, який ілюструє розбіжності між значеннями відносних ваг альтернатив, що отримані на основі групових парних порівнянь, відповідно, з урахуванням, та без урахування відносної компетентності експертів. 
Нехай 3 експерти $\left(E_{1}, E_{2}, E_{3}\right)$ попарно порівнюють 4 альтернативи $\left(A_{1}, A_{2}, A_{3}\right.$, $\left.A_{4}\right)$, обираючи для введення парних порівнянь ціло-чисельні шкали 3 кількістю поділок від 2 до 9. В контексті даного прикладу для наочності вважатимемо апріорні оцінки відносної компетентності (що відображають взаємну оцінку, самооцінку та об'єктивну оцінку) рівними: ( $c_{1}=c_{2}=c_{3}=1$, відповідно, нормовані значення $\left.c_{1}=c_{2}=c_{3}=1 / 3\right)$. У прикладі застосовується адитивний вигляд функції рейтингу МПП (формула (8)).

Матриці ординальних парних порівнянь показані у табл. 1. Нехай ординальні оцінки є добре узгодженими, тобто можна відсортувати альтернативи таким чином, що усі парні порівняння вище головної діагоналі кожної з МПП будуть більшими за 1. Нехай перший експерт не в змозі порівняти першу і третю альтернативи. Це означає, що відповідна МПП є неповною, інформаційно-значимі множини, які містять дане парне порівняння з МПП першого експерта, не є інформаційно-змістовними, а відтак, відповідні множники у добутку (формула (9)) дорівнюватимуть 1.

Таблиця 1. Матриці ординальних парних порівнянь чотирьох альтернатив трьома експертами

\begin{tabular}{c|c|c|c|c|c|c|c|c|c|c|c|c}
\hline \hline & \multicolumn{5}{|c|}{$E_{1}$} & \multicolumn{6}{c|}{$E_{2}$} & \multicolumn{4}{c}{$E_{3}$} \\
\hline \hline & $A_{1}$ & $A_{2}$ & $A_{3}$ & $A_{4}$ & $A_{1}$ & $A_{2}$ & $A_{3}$ & $A_{4}$ & $A_{1}$ & $A_{2}$ & $A_{3}$ & $A_{4}$ \\
\hline$A_{1}$ & 1 & $>$ & $*$ & $>$ & 1 & $>$ & $>$ & $>$ & 1 & $>$ & $>$ & $>$ \\
\hline$A_{2}$ & & 1 & $>$ & $>$ & & 1 & $>$ & $>$ & & 1 & $>$ & $>$ \\
\hline$A_{3}$ & & & 1 & $>$ & & & 1 & $>$ & & & 1 & $>$ \\
\hline$A_{4}$ & & & & 1 & & & & 1 & & & & 1 \\
\hline \hline
\end{tabular}

У табл. 2 наведено кількості поділок у шкалах, які троє експертів обирають для введення відповідних парних порівнянь. У табл. 3 - номери поділок відповідних шкал. У табл. 4 наведені МПП трьох експертів, що містять значення парних порівнянь, приведених до найдетальнішої шкали з 9-ти поділок (1 - немає переваги, 2 - слабка перевага, 3 - середня, 4 - більш ніж середня, 5 - сильна, 6 більш ніж сильна, 7 - дуже сильна, 8 - дуже-дуже сильна, 9 - надзвичайна; а також - обернені значення та співвідношення) за правилами, викладеними у [21]. Приведене значення (отримане шляхом перетворень значень з іншої шкали) не завжди точно співпадає з поділкою. Парне порівняння, пропущене експертом, замінюється на 1 («відсутність будь-якої переваги»).

Таблиця 2. Кількість поділок у шкалах, які вибрані експертами для введення відповідних парних порівнянь

\begin{tabular}{c|c|c|c|c|c|c|c|c|c|c|c|c}
\hline \hline & \multicolumn{5}{|c|}{$E_{1}$} & \multicolumn{5}{c|}{$E_{2}$} & \multicolumn{4}{c}{$E_{3}$} \\
\hline \hline & $A_{1}$ & $A_{2}$ & $A_{3}$ & $A_{4}$ & $A_{1}$ & $A_{2}$ & $A_{3}$ & $A_{4}$ & $A_{1}$ & $A_{2}$ & $A_{3}$ & $A_{4}$ \\
\hline$A_{1}$ & 1 & 9 & $*$ & 7 & 1 & 3 & 4 & 5 & 1 & 9 & 9 & 8 \\
\hline$A_{2}$ & & 1 & 6 & 5 & & 1 & 6 & 7 & & 1 & 3 & 9 \\
\hline$A_{3}$ & & & 1 & 4 & & & 1 & 8 & & & 1 & 7 \\
\hline$A_{4}$ & & & & 1 & & & & 1 & & & & 1 \\
\hline \hline
\end{tabular}


Таблиця 3. Номери поділок у вибраних експертами шкалах парних порівнянь

\begin{tabular}{c|c|c|c|c|c|c|c|c|c|c|c|c}
\hline \hline & \multicolumn{5}{|c|}{$E_{1}$} & \multicolumn{6}{c|}{$E_{2}$} & \multicolumn{4}{c}{$E_{3}$} \\
\hline \hline & $A_{1}$ & $A_{2}$ & $A_{3}$ & $A_{4}$ & $A_{1}$ & $A_{2}$ & $A_{3}$ & $A_{4}$ & $A_{1}$ & $A_{2}$ & $A_{3}$ & $A_{4}$ \\
\hline$A_{1}$ & 1 & 2 & $*$ & 7 & 1 & 3 & 4 & 5 & 1 & 2 & 4 & 8 \\
\hline$A_{2}$ & & 1 & 3 & 4 & & 1 & 2 & 4 & & 1 & 2 & 4 \\
\hline$A_{3}$ & & & 1 & 2 & & & 1 & 2 & & & 1 & 3 \\
\hline$A_{4}$ & & & & 1 & & & & 1 & & & & 1 \\
\hline \hline
\end{tabular}

Таблиця 4. Значення парних порівнянь, приведені до найдетальнішої шкали

\begin{tabular}{c|c|c|c|c|c|c|c|c|c|c|c|c}
\hline \hline & \multicolumn{4}{|c|}{$E_{1}$} & \multicolumn{4}{c|}{$E_{2}$} & \multicolumn{4}{c}{$E_{3}$} \\
\hline \hline & $A_{1}$ & $A_{2}$ & $A_{3}$ & $A_{4}$ & $A_{1}$ & $A_{2}$ & $A_{3}$ & $A_{4}$ & $A_{1}$ & $A_{2}$ & $A_{3}$ & $A_{4}$ \\
\hline$A_{1}$ & 1 & 2 & 1 & $85 / 6$ & 1 & $71 / 2$ & $81 / 6$ & $81 / 2$ & 1 & 2 & 4 & 9 \\
\hline$A_{2}$ & $1 / 2$ & 1 & $38 / 9$ & $61 / 2$ & $1 / 7$ & 1 & $22 / 7$ & $45 / 6$ & $1 / 2$ & 1 & $31 / 2$ & 4 \\
\hline$A_{3}$ & 1 & $1 / 4$ & 1 & $25 / 6$ & $1 / 8$ & $3 / 7$ & 1 & 2 & $1 / 4$ & $2 / 7$ & 1 & $31 / 2$ \\
\hline$A_{4}$ & $1 / 8$ & $1 / 6$ & $1 / 3$ & 1 & $1 / 8$ & $1 / 5$ & $1 / 2$ & 1 & $1 / 9$ & $1 / 4$ & $2 / 7$ & 1 \\
\hline \hline
\end{tabular}

На основі матриць, що наведені у табл. 4 будуються 48 ІУМПП $\left(m n^{n-2}=3 \times 4^{2}=48\right)$. Для порівняння кожної з цих матриць 3 реальною матрицею, робиться 3 ії копії (за числом експертів). Тобто, загальна кількість ІУМПП, що аналізуються, а відтак, множників у добутку (формула (9)) дорівнює $T=m^{2} n^{n-2}=$ $=144$.

Так, наприклад, ІУМПП, отримана за 1-м рядком МПП 2-го експерта дорівнює:

$$
\left(\begin{array}{cccc}
1 & 7 \frac{1}{2} & 8 \frac{1}{6} & 8 \frac{1}{2} \\
1 / 7 & 1 & 1 & 1 \frac{1}{8} \\
1 / 8 & 1 & 1 & 1 \\
1 / 8 & 8 / 9 & 1 & 1
\end{array}\right) .
$$

Аналогічним чином будуються 48 ІУМПП, які порівнюються з початковими МПП з табл. 4. За формулою (8) обчислюються рейтинги 144-х матриць (якщо у базисній множині бракує парного порівняння, яке не задав перший експерт, то вона не $\epsilon$ інформаційно-змістовною, і рейтинг відповідної матриці дорівнює 0). Після цього рейтинги нормуються за сумою (див. показник степеня у формулі (9)). Паралельно, за кожною з ІУМПП будуються вектори ваг альтернатив. Як ненормований вектор ваг можна брати будь-яку базисну множину парних порівнянь, наприклад, останній рядок матриці. Після цього за формулою (9) обчислюються ненормовані агреговані значення ваг альтернатив, які потім нормуються. Наголосимо, що від експертів вимагається тільки введення вербальних еквівалентів парних порівнянь у найбільш зручних шкалах. Усі обчислення виконуються машинним шляхом.

Нормовані ваги альтернатив, обчислені за формулою (9) з урахуванням відносних коефіцієнтів компетентності та за формулою (7) без урахування цих коефіцієнтів, наведені в табл. 5. 
Таблиця 5. Ваги альтернатив, обчислені з урахуванням і без урахування компетентності експертів

\begin{tabular}{l|c|c|c|c}
\hline \hline & $W_{1}$ & $W_{2}$ & $W_{3}$ & $W_{4}$ \\
\hline \hline З урахуванням компетентності (формула (9)) & 0,533 & 0,264 & 0,133 & 0,071 \\
\hline Без урахування компетентності (формула (7)) & 0,547 & 0,269 & 0,129 & 0,054 \\
\hline Відмінність (у \%) & 2,6 & 1,9 & 3,0 & 23,9 \\
\hline \hline
\end{tabular}

Як бачимо, незважаючи на ідеальну ординальну та високу кардинальну узгодженість початкових даних, а також на використання адитивної (а не мультиплікативної) формули обчислення рейтингу ІУМПП, між результатами, отриманими методом простого та зваженого середнього геометричного, спостерігаються відмінності. При цьому, найсуттєвіші відмінності спостерігаються між найменшими вагами альтернатив. Приклад підтверджує інтуїтивний загальний висновок про те, що чим менш узгодженими є вихідні дані, тим значніший вплив на результати експертизи справляють відповідні компоненти показника відносної компетентності експертів. Подальші дослідження будуть спрямовані, зокрема, на більш грунтовний експериментальний аналіз удосконаленого методу агрегації.

\section{Висновки}

Показано, що для визначення відносної компетентності члена експертної групи під час групових парних порівнянь не достатньо обмежуватися самооцінкою, взаємною оцінкою, та об'єктивною компонентою, які характеризують загальні рівні опису предметної області: доцільно враховувати також показники, які відбивають внутрішню узгодженість експертних парних порівнянь, взаємну узгодженість оцінок, наданих різними членами групи, повноту експертних даних та ступінь деталізації знань експерта про кількісне співвідношення конкретної пари об'єктів, що порівнюються.

Запропоновано метод обчислення коефіцієнтів відносної компетентності членів експертної групи. У запропонованому методі, окрім апріорних значень компетентності експертів у контексті предметної області взагалі, враховується рівень докладності шкал, у яких вводяться парні порівняння, а також рівень внутрішньої і взаємної узгодженості матриць парних порівнянь.

Отримано експериментальні результати, які вказують на суттєві відмінності між результатами експертиз, що проводяться, відповідно, без урахування та з урахуванням усіх аспектів і складових компетентності експертів.

Основною перевагою методу порівняно з іншими наявними методами визначення компетентності експертів $є$ його універсальність, тобто можливість одночасного врахування усіх аспектів компетентності експерта (апріорної оцінки, повноти, узгодженості та докладності даних), а не якоїсь одної компоненти показника.

Описаний у статті механізм визначення відносної компетентності експертів дозволяє удосконалити методи агрегації групових парних порівнянь (зокрема, комбінаторний метод) і зробити результати їхнього застосування більш достовірними, тобто такими, що відображають реальний рівень компетентності учасників експертиз. 
Подальші дослідження будуть спрямовані, зокрема, на експериментальне дослідження удосконаленого комбінаторного методу агрегації парних порівнянь на реальних експертних даних.

Статтю підготовлено в рамках проекту Ф73/23558 «Розробка методів і засобів підтримки прийняття рішень при виявленні інформаційних операцій». Проект $\epsilon$ переможцем конкурсу Ф73 на грантову підтримку науково-дослідних проектів Державного фонду фундаментальних досліджень і Білоруського республіканського фонду фундаментальних досліджень.

1. Tsyganok V., Kadenko S., Andriichuk O. Significance of expert competence consideration in group decision making using AHP. International Journal of Production Research. 2012, Vol. 50. Issue 17. P. 4785-4792.

2. Dreyfus S.E., Dreyfus H.L. A Five-Stage Model of the Mental Activities Involved in Directed Skill Acquisition (PDF). Washington, DC: Storming Media, 1980. URL: https://www.researchgate.net/ publication/235125013_A_Five-Stage_Model_of_the_Mental_Activities_Involved_in_Directed_Skill_ Acquisition

3. Dreyfus S.E. The Five-Stage Model of Adult Skill Acquisition. Bulletin of Science Technology \& Society 2004 24: 177. DOI: 10.1177/0270467604264992.

4. Ельмеев В.Я., Овсянников В.Г. Прикладная социология. Очерки методологии. 2-е изд., испр. и доп. Санкт-Петербург: Изд-во. СПГУ, 1999. 296 с.

5. Миркин Б.Г. Проблема групового выбора. Москва: Наука, 1974. 256 с.

6. Литвак Б.Г. Экспертная информация. Методы получения и анализа. Москва: Радио и связь, 1982.185 с.

7. Saaty T.L. 1994. Fundamentals of Decision Making and Priority Theory with The Analytic Hierarchy Process. / T.L.Saaty; RWS Publications, Pittsburgh PA, 204220.

8. Ramanathan R., Ganesh L.S. Group Preference Aggregation Methods Employed in AHP: An Evaluation and Intrinsic Process for Deriving Members' Weightages. European Journal of Operational Research. 1994. 79. P. 249-265.

9. Forman E., Peniwati K. Aggregating individual judgments and priorities with the analytic hierarchy process. European Jouranl of Operational Research. 1998. Vol. 108. P. 131-145.

10. Гнатієнко Г.М., Снитюк В.Є. Експертні технології прийняття рішень. Київ: ТОВ «Маклаут», 2008. $444 \mathrm{c}$.

11. Тоценко В.Г. Методы и системы поддержки принятия решений. Алгоритмический аспект. ИПРИ НАНУ. Київ: Наукова думка, 2002. 382 с.

12. Аверченков В.И., Ерохин В.В. Системы организационного управления: учеб. пособ. 3-е изд., стереотипное. - Москва: Изд-во «ФЛИНТА» 2011. 208 с.

13. Yang Q, Du P-a, Wang Y, Liang B. A rough set approach for determining weights of decision makers in group decision making. PLoS ONE 12(2). 2017: e0172679. doi:10.1371

14. Таран Т.А., Зубов Д.А. Искусственный интеллект. Теория и приложения. Восточноукр. нац. ун-т им. Владимира Даля. Луганск: ВНУ им. В.Даля, 2006. 239 с.

15. Hwang C.L., Yoon K. Multiple attribute decision making: methods and applications: a stateof-the-art survey. Berlin, New York: Springer-Verlag, 1981.259 p.

16. Волошин О.Ф., Гнатієнко Г.М. Процедури визначення компетентності експертів. Вісник Київ. ун-ту. Фіз.-мат. науки. 1993. № 3. С. 102-111. 
17. Самохвалов Ю.Я., Науменко Е.М. Экспертное оценивание. Методический аспект. Киев, 2007. 263 c.

18. Циганок В.В., Каденко С.В., Андрійчук О.В., Качанов П.Т., Роїк П.Д. Інструментарій підтримки прийняття рішень як засіб стратегічного планування. Озброєння та військова техніка. 2015. № 3(7). С. 59-66.

19. Чепков І.Б., Ланецкий Б.М., Леонтьєв О.Б., Лук’янчук В.В. Методичний підхід до обгрунтування раціонального співвідношення обсягів розробки, закупівлі та ремонту озброєння й військової техніки. Озброєння та військова техніка. 2014. № 3. С. 9-14.

20. Циганок В.В. Комбінаторний алгоритм парних порівнянь зі зворотним зв'язком з експертом. Реєстрація, зберігання і обробка даних. 2000. Т. 2. № 2. С. 92-102.

21. Tsyganok V.V., Kadenko S.V., Andriichuk O.V. Using Different Pair-wise Comparison Scales for Developing Industrial Strategies. Int. J. Management and Decision Making. 2015. Vol. 14. N 3. P. 224-250.

22. Kruger J., Dunning D. Unskilled and Unaware of It: How Difficulties in Recognizing One's Own Incompetence Lead to Inflated Self-Assessments. Journal of Personality and Social Psychology. 1999. 77(6). Р. 1121-1134.

23. Циганок В.В. Метод обчислення ваг альтернатив на основі результатів парних порівнянь, проведених групою експертів. Реєстрація, зберігання і обробка даних. 2008. Т. 10. № 2. С. $121-127$.

24. Hartley R.V.L. Transmission of information. Bell System Technical J. 1928. 7. P. 535-563.

25. Cayley A. A Theorem on Trees. Quarterly Journal of Mathematics. 1889. Vol. 23. P. 376-378.

26. Tsyganok V. Investigation of the aggregation effectiveness of expert estimates obtained by the pairwise comparison method. Mathematical and Computer Modeling. 2010. 52(3-4). P. 538-544.

Надійшла до редакції 01.06.2017 